\title{
EXTERNAL EXPERIENCE FOR THE EXECUTION OF EXCHANGE REGULATION AND POSSIBILITIES OF ITS APPLICATION IN UKRAINE
}

\author{
Yevgen Barash ${ }^{1}$ \\ Institute of Penal Service, Ukraine \\ Yurii Kryvytskyi² \\ National Academy of Internal Affairs, Ukraine \\ Sergii Ablamskyi ${ }^{3}$ \\ Kharkiv National University of Internal Affairs, Ukraine
}

\begin{abstract}
The aim of the article is to conduct a comparative legal study of statutory legal acts, which define the legal framework for the implementation of currency regulation in some foreign countries and in Ukraine and which determine on this basis ways to improve domestic legislation in this area. The subject of the research is the experience of currency regulation in some European countries, USA, China, and Ukraine. Methodology. The research is based on a comparison of foreign exchange regulation in Ukraine and in foreign countries. Advantages and disadvantages of different modes of state control over currency circulation are determined, on the basis of the analysis of peculiarities of the state regulation of currency circulation in the United Kingdom, Germany, France, Poland, the USA, China, and in some other countries: from floating rate regime to rigorous state control. On the basis of the comparative legal study of certain provisions of the administrative legislation of Ukraine, the possibilities and limits of the application of positive foreign experience in this field are determined. The results of the study have shown that in order to implement foreign exchange management experience, it is necessary to postpone the final transition untill establishing a floating rate regime. It is possible to make it by reinforcing state interference. At the same time, it is necessary to strengthen currency control not only over the implementation of foreign exchange operations but also over the activities of subjects that determine the state policy in the field of currency regulation, as well as over those, who directly carry out the corresponding activity using the tools specified by provisions of the current legislation. Practical impact. The positive experience of the formation of the foreign exchange market in foreign countries shows that the gradual transition from a fixed to a floating exchange rate is the beginning of a natural market exchange rate and the equalization of the balance of payments and the gradual release of the national economy from the pressure of administrative and corruption restrictions. Value/originality. Conducting the comparative analysis of foreign exchange regulation in foreign countries is the basis for developing the most promising directions for the development of domestic legislation in this field.
\end{abstract}

Key words: foreign experience, currency regulation, exchange rate, currency control, EU countries.

JEL Classification: F31, F33, 024

\section{The problem statement}

Today, the Ukrainian government faces an important task: to provide a stable hryvnia exchange rate, to strengthen the national economy of the country, to raise the level of well-being of each individual citizen. One of the main ways to solve these problems is the implementation of the effective currency regulation. However, it is sad to note that the state of currency regulation in our country leaves much to be desired, which can be proved by: firstly, the constant fluctuation of the exchange rate; and secondly, high inflation and depreciation of the hryvnia; thirdly, a sharp increase of the poverty, a decrease in its purchasing power; fourthly, the weakening of Ukraine's position in the international market. The issue of improving the legal framework for the implementation of currency regulation is

\footnotetext{
Corresponding author:

${ }^{1}$ Institute of Penal Service.

${ }^{2}$ Department of Theory of State and Law, National Academy of Internal Affairs.

${ }^{3}$ Department of Criminal Procedure and Organization of Pre-Trial Investigation, Kharkiv National University of Internal Affairs.
} 
particularly acute under such conditions. We should pay a special attention to foreign exchange regulation experience in this context. If we will analyse the positive experience of the leading countries of the world, it will help to identify weaknesses in domestic legislation and suggest solutions to these problems.

\section{The state of research}

V.I. Mischenko, A.S. Galchinskyi, Yu.M. Bezditko, O.I. Kabanets, V.D. Kolga, O.V. Boryshkevych, I.V. Krasnov, V.S. Biloshapka, O.O. Manuilenko, O.A. Kostiychenko, E.O. Alisov, L.K. Voronova, Yu.V. Vashchenko, S.V. Mochernyi, O.V. Dziublyk, V.I. Harkavenko and many other scientists studied some of the problematic issues of currency regulation.

However, despite a large number of scientific researches, there is no single comprehensive study, which is devoted to foreign experience in the implementation of currency regulation.

That is why the aim of the article is: to consider foreign experience in the implementation of currency regulation and to determine possibilities for its application in Ukraine.

\section{Statement of the basic material}

Considering the foreign experience of currency regulation, in our opinion, it is necessary to draw attention to three aspects: first, the experience of the EU; and second, we need to consider how currency regulation takes place in the United States; thirdly, it is necessary to pay attention to the countries of the east and, in particular, to China. Among the countries of the European Union, first of all, we want to talk about Great Britain, who left EU and it was one of the most acute and debated issues in 2017. But, actually, the official secession of the kingdom from the EU should take place on March 29, 2019, at 23:00 London time, and only after the UK will fulfil all the necessary conditions.

The active development of currency regulation in Britain began after the end of the Second World War. The devaluation of 1949 did not solve problems of the English currency. The progressive deterioration in the balance of payments, which began in 1964, had led to the fact that neither foreign lending nor the raising of the discount rate by the Bank of England could stop the decline in official gold and foreign currency reserves. Every time, when the state of the balance of payments deteriorated, there were mass transactions involving the sale of pounds sterling, which worsened the currency position of the country even more. In November 1967, a second post-war devaluation was held at $14.3 \%$. The pound sterling to the dollar had fallen to 2.4 dollars. This devaluation was supplemented by credit and financial constraints, the impact of which reflected the balance of payments situation after 1.5 years.
In 1969-1971 years, England had a positive balance on current operations. Therefore, in December 1971, the pound sterling was revalued against the dollar. The new rate was $\$ 2.6$. But this stabilization was shortlived (Shamova, 2007). The sharp deterioration of the balance of payments in 1972 forced the British government to establish a floating exchange rate regime for its currency. From this period began a sharp decline in the rate. In 1976, it dropped by $40 \%$ compared with 1971. The crisis of confidence in the pound sterling had led to the fact that since 1976, the government had a policy of restricting its role as a reserve currency, which accelerated the final disintegration of the sterling zone, which by the end of the 70s stopped to exist. Since mid of 1977, the pound sterling strengthened against the dollar. It was connected with the wave of capital into the country due to the start of oil production in the North Sea during the oil crisis. But due to the economic crisis of the 1979-1982 years, the outflow of capital from the country began and a tendency to depreciate the pound sterling appeared again. In recent years, one of the reasons why Britain did not join the countries, which introduced the euro to the non-cash circulation since 1 January 1999, was the increase in the rate of this currency (Shamova, 2007). The Bank of England used various instruments in its fight with the inflation. The neo-Keynesian approach to currency regulation prevailed by the end of the 1970s. Three methods were used: the change in the interest rate of the Bank of England, the change in the provisions of the reserve, and the direct selective methods of controlling the bank loans to the private sector. The main instrument of selective regulation was the so-called credit limits, that is, the establishment of quantitative limits on loans to the private sector. Such limits were added with the instructions from the Bank of England, about categories of borrowers, to whom should be given benefits in lending. Besides, various restrictions on the purchase of commercial bills by commercial banks and discount companies were introduced, the terms of consumer credit were regulated, etc. (Shamova, 2007).

Starting from May 11, 1999, the Bank of England publishes a daily index of the exchange rate efficiency, taking into account the volume of trade in the Eurozone. It is necessary to note that the main feature of Great Britain is that the currency control system does not exist in it, so you can actually buy back or return as much money as you want. You just need to declare about the import of foreign currency in your customs declaration but there is no legal prohibition to physically move money to and from the country. Due to the fact that the United Kingdom is still a member of the European Union, there is still no control or obstacle to the transfer of money beyond its borders because each EU member state is governed by the same European laws, that is, it does not hinder the movement of the currency. The main regulatory act in the field of currency regulation in 
the UK is the Law "On Currency Control". Provisions of this law provide authority and impose obligations and restrictions in the field of currency exchange. The currency control bodies include the Treasury, the Bank of England and authorized banks that have a currency license, as well as customs and excise authorities. The British Treasury is the main body of currency control. However, most of its powers, it has delegated to the Bank of England, which directly exercises currency control. The Bank of England manages its affiliates and authorized representative offices in most commercial banks (both domestic and foreign), which are located in the UK and which execute a wide range of transactions with its permission. Customs and excise authorities control the movement of capital and currency across borders (Shmyreva, 1999).

We need to note that the UK legislation lacks the rules that oblige participants in currency relations to ensure the receipt of foreign exchange earnings from non-residents on their bank accounts. If the price of the imported goods is not established in the British national currency, the conversion of other types of currencies to the British is made according to the average monthly rates. It should also be noted that on the UK Government website, there is information that, in the case of payments for goods exported in foreign currency, exporters may experience a currency exchange difference due to exchange rate fluctuations. Besides, on this website, you can find recommendations about how to avoid or minimize potential losses during conversion.

Talking about German experience of currency regulation, we should point out, first of all, that this country has an open and attractive attitude towards foreign direct investment. The legal framework for FDI in Germany contributes to the principle of freedom of foreign trade and payment transactions, as it is provided by the Law "On Foreign Trade and Payments" (Außenwirtschaftsgesetz).This legal act allows you to set restrictions on foreign direct investment both externally and abroad due to the reasons of foreign policy, foreign currency or national security. However, in practice, such restrictions are rarely imposed. We should note separately that, in cooperation with other EU members, Germany has an impressive arsenal of rules and institutional procedures aimed at the implementation of currency regulation.

In fact, in Germany, currency regulation is carried out by the European Central Bank, which is in Frankfurt, and it is headed by a multinational commission of delegates from the central banks of the participating countries. The German central bank, Deutsche Bundesbank, is responsible for the coinage of deutschemarks in circulation. It also sends representatives to the Board of Directors of the European Central Bank. Within Germany, it exercises various supervisory functions in the banking system, acting jointly with the Federal Financial Supervision Authority. Considering the experience of Germanyin the field of currency regulation, we should also pay attention to the system of currency control. The system of currency control in Germany is based on such legislative acts as: the Federal Law "On the German Federal Bank" (Bundesbank), the Federal Law "On Foreign Exchange Turnover and Control of Goods" (Foreign Exchange Act) (Khamaganova, 2001). According to German legislation, the exclusive competence in the field of capital movements and the operation of foreign exchange operations is owned by the Federal Bank. It should be noted that although there is the presence of a free movement of capital in Germany, there is also control in the form of accounting for capital, which crosses the state border. Information on the movement of capital across borders is collected and transmitted through banks and lending institutions to the Bundesbank, where a data analysis is conducted. This analysis allows developing specific measures for the regulation of the foreign exchange market (Platonova, 2006). As a result of the liberalization of currency control in Germany, the issue of organizing counteraction to the use of financial systems for the purpose of money laundering, which was received by criminal means, became acuter. The Federal Law "On the Identification of Revenues Gained as a Result of Serious Criminal Offenses" was adopted in 1993 in order to solve this issue. In accordance with this Law, the function of controlling financial operations is assigned to the Federal Bank of Germany. Thus, the system of currency control in Germany serves as a control over financial transactions with foreign currency, counteracting the legalization of criminal proceeds (Lisovol, 2017).

France is another EU country that we will focus on. It should be noted that the general principles for the implementation of currency regulation are determined by the European Central Bank. Besides, the currency control in France was introduced in accordance with the Law on Currency Regulation and Control in September 1939. So, it was the beginning of the Second World War, when France had significant problems in the monetary and financial sphere, foreign exchange controls covered all types of foreign exchange operations. The currency control bodies in France at that time were: the Ministry of Finance, in whose structure the Treasury Department was engaged in the development of strategic directions in the field of currency regulation and control, and the Main Customs Office exercised control over currency transactions of a "commercial" character, as well as non-trading operations, which are connected with the movement of currency values across the border; National Bank of France, which regulated and controlled financial transactions in foreign and national currency (credits, loans) (Luchkovska, 2005).

Another country, which experience can be useful, is Poland because this state simultaneously with Ukraine is on the way of democratization of its society. In Poland, a fixed exchange rate regime was introduced 
with the beginning of the reform process - first to the US dollar, and then to the "basket" of five leading currencies, in order to curb inflation. In May 1995, the regime for fixing the exchange rate was changed to "currency corridor", the limits of which were gradually expanding from $\pm 7 \%$ to $\pm 15 \%$. Since April 2000, as a result of the introduction of free floatation of the exchange rate, different market factors are beginning to affect the Polish zloty course. In the mid-90s of the XX century, the National Bank of Poland began to use actively exchange rate policy in the fight against inflation. The strengthening of the zloty's exchange rate in 2000-2001 was the result of large revenues from privatization and a consistent restrictive monetary policy of the Polish government, as well as the inflow of foreign capital (Honcharuk, Matsko, Shparhalo, 2010). On July 27, 2002, a new Law "On Foreign Currency" was issued in Poland, which regulated the execution of foreign exchange transactions. This law abolished all restrictions on the movement of funds between Poland and the EU countries. At the same time, the law provides some restrictions regarding the movement of funds from non-EU countries. Currency restrictions can be removed by obtaining currency permits. These permits can be of two types: general and private. The general currency permits are issued by the Ministry of Finance, and private ones - by the National Bank of Poland (Sorokivska, 2013).

The main measure of currency regulation was the transition to a flexible exchange rate and the introduction of the "free-swimming" regime in 2000. This regime can be characterized by the fact that in the process of establishing a currency exchange rate in the currency market, there is an influence of the central bank of the country, which aligns the sharp short-term, and sometimes medium-term fluctuations of the rate in order to make it more predictable and stimulating foreign trade (Khamaganova, 2001; HarbinskaRudenko, 2011). Currency exchange rate systems in the country are often characterized by the simultaneous diversity of exchange rates, each of which is used for another set of transactions. Multi-rate regimes can be applied when more than one course is claimed for the purchase and sale of currencies or when the purchase and sale rates differ by more than $2 \%$ (the smaller difference between the purchase and sale rates is used to cover the cost of transactions with foreign currency and it does not involve the presence of multiple rates). Poland's move to the euro was planned in 2007, but now Polish politicians support the introduction of the European currency as later. The country's path towards a single European currency will depend on whether the government can able to effectively reform the public financial system (Harbinska-Rudenko, 2011).

The policy of currency regulation in Poland is realized through the mechanism of currency restrictions and currency control. The purpose of currency control is to ensure compliance of residents and non-residents with currency legislation (Ivanov D., 1998; HarbinskaRudenko, 2011). The system of currency control in Poland is carried out on the basis of the Law "On Foreign Exchange Regulation and Currency Control in Poland". The National Bank of Poland is the main body that determines the currency policy of the country. The main component of foreign exchange policy is the introduction of a mechanism for adjusting the country's balance of payments, which is one of the most important macroeconomic aspects of the NBP's activities. In order to determine the strategies of currency exchange and monetary policy and the reform of the external sector of the economy, the National Bank of Poland also develops the forecast of the balance of payments, which can be used as a basis for negotiations with international organizations on the provision of financial assistance to the country (Yurhelevych, 2000).

In the context of this scientific study, we need to draw attention to the experience of the United States of America. The US government uses various currency regulation means that are implemented by the Central Bank of the country. So, one of the first means is to change the exchange rates when the Bank raises or decreases the rate of accumulated funds. For example, if a bank reduces the rate, it leads to a reduction in the interest rate throughout the US banking system, which reduces the supply of money, affects the value of loans, that is, makes these loans more expensive. All this, in turn, makes the dollar stronger and more stable in comparison with other currencies. At the same time, assets in dollar equivalent provide greater profitability. A similar situation creates more demand for the dollar, bringing it out of circulation. The laws of supply and demand show that a smaller supply and more demand increase the price. When it comes to the dollar, it makes it possible to buy more foreign currency in the forex markets.

The next is the Treasury Department of the United States, which is a government agency that also indirectly affects the exchange rate. It prints more money, which increases the offer, weakening the dollar. The department can also get a loan from other countries, which can be done through the sale of gold reserves from the state treasury. This not only increases the offer of money but also increases the debt. The third government instrument for the currency regulation in the United States is an expansionist (stimulating) fiscal policy. Such a policy weakens the dollar by increasing the money supply but, at the same time, it generally has a positive effect on the country's economy, ensuring economic growth, and contributes to the increasing confidence in the country's economy from the investor's side. Sometimes this demand is so high that investors do not notice low-interest rate that they will receive by investing money in the economy. Quite often there are cases where demand is even greater than the offer. 
When considering currency regulation in the USA, it is necessary to pay attention to the fact, how the Government regulates foreign exchange trade. So, the Chicago Chamber of Commerce regulates activities of brokers in the forex market. The Chamber supervises all American forex brokerage companies, establishes its rules, and conducts criminal proceedings in case of violation of the rules of the current legislation. The power of the Chamber was strengthened in 2010 by the Dodd-Frank Wall Street Reform Act. Approximately 95 percent (which is almost $\$ 5.3$ trillion) traded daily in the forex markets are currency transactions, not futures. Brokers should register as Trade Advisers, or as futures trading dealers, and become members of the NFA (National Futures Association). The American National Futures Association is a self-regulating association. The purpose of the association is to protect the integrity of the US markets and protect investors from fraud. But this is not related to the value of any particular currency.

In the conclusion, we want to say that changes in the exchange value of the dollar are an important factor for monetary policy since such an activity affects economic activity and prices in the United States. In addition, it should be noted that although the US monetary policy is not aimed at establishing a certain level of the dollar, however, taking into account the importance of the dollar's impact on US prices and economic activity at the international level, this business direction is important both for the United States of America itself and for many other countries in the world.

A special attention, in our opinion, we should pay to the experience of China. Today the leading economists of the world recognize the economy of this state as one of the most powerful in the world, and its currency is perhaps the most stable one. There are currently two main provisions in China that define the key principles for the currency regulation and control over the foreign exchange market and other financial institutions. The following legal rules are: "Rules of the People's Republic for the Implementation of Currency Control" and "Administrative Provisions on Currency Settlements, Sales and Payments".

If we talk about the rules, they include 12 chapters, which are connected with the foreign exchange market and financial institutions. Six of these chapters are aimed at regulating currency transactions of financial institutions. Other provisions are aimed at regulating the exchange rate of the yuan and the foreign exchange market. Thus, Articles 33 and 36 regulate the exchange rate of the yuan and the corresponding control over foreign currency borrowing by banks. These two articles assume that the exchange rate of the yuan is floating and is based on the market demand and supply. Dealers in the interbank foreign exchange market are special banks and other financial institutions involved in foreign currency transactions. They can set purchase and sale rates for their clients and trade in foreign currency. It should also be noted that Article 27 of the Rules defines the principles for the functioning of the currency business of financial institutions in China. It stipulates that financial institutions require from SAFE approval to conduct transactions with foreign currency, as well as to require a license for such transactions. Neither organization nor individual can operate foreign currency without the approval of SAFE. Financial institutions have all the necessary tools to be able to earn a foreign currency but they cannot operate outside the approved scope. When considering "Administrative Provisions for Currency Settlements, Sales and Payments", it should be noted that this package of Provisions is applied to regulate the retail trade market between yuan and foreign currencies. Article 35 of the mentioned legal act defines the principles for the control of the exchange rate, and Articles 2, 34, and 39 define the principles for exercising control over the activities of authorized financial institutions.

Besides, special provisions on the exchange rate of the yuan should be defined, in particular:

- A circular on Exchange Rate Management and Exchange of Operational Information, issued March 23, 1995.

- A circular on the foreign exchange market and the participation of a foreign investment enterprise in the system of bank replacement and sale on a currency exchange, issued on June 28, 1996. This legal act provides that foreign companies are allowed to participate in the currency market of China, where you can sell and buy yuan at the official rate. Also, enterprises have an opportunity to constantly sell and buy yuan in the currency market. This Provision also regulates the distribution of the exchange rate of yuan with 13 foreign currencies, which are listed in the business plan of currency banking supervision;

- Official response of the State Currency of the Exchange Administration to the Chinese currency trading system about the beginning of the exchange of currencies in the foreign exchange market of Ukraine in the interbank foreign exchange market, issued on January 14, 2002.

Separately, in our opinion, it is necessary to indicate the provisions defining the main principles of the activities of authorized financial institutions, in particular: 1) Provisions on the foreign exchange business of banks, issued on September 27, 1997; 2) Provisions on the definition of operations of foreign exchange business of banks, issued on May 16, 1996; 3) Provisions on currency exchange business of financial institutions purchasing money, issued on January 1, 1993; 4) "On Definition of Foreign Currency Transactions for NonBank Financial Institutions", issued on May 16, 1996; 5) Provisions on foreign financial institutions of the People's Republic of China, which was originally issued on April 1, 1994; 6) Detailed rules for the regulation of foreign financial institutions of the People's Republic of China, issued on January 30, 2002; etc. 
Thus, currency regulation in China is characterized by rigorous control from the state's side. Besides, it is important to mention a rather wide list of normative legal acts that define both the legal basis for the implementation of currency regulation and the principles of the activity of authorized state authorities. The effectiveness of currency regulation in China also proves the rapid growth of the economy of this country over the past and a half decades.

\section{Conclusions}

At the end of the submitted scientific research, we want to say that Ukraine is a young state, which stands on the way of carrying out deep reforms not only in the field of currency regulation but also the whole economy in general. The legislator in order to implement the foreign experience of currency regulation in Ukraine, it is necessary to do such things as:

- wait with the definitive establishment of the floating rate regime, by intensifying state interference. In this regard, we note that in fact in Ukraine, there has already been a transition from a fixed to floating exchange rate, which ideally should become the beginning of a natural market exchange rate, equalization of the balance of payments, and the gradual release of the economy from the pressure of administrative and corruption restrictions. However, practice has shown that such a situation: first, allows earning officials, who are not honest; second, the country's population is not yet ready for such changes, because at the first fluctuation of the currency, there is some kind of panic, which in turn has a negative impact on the economy as a whole;

- it is necessary to strengthen currency control not only for the implementation of foreign exchange operations but also for the activities of entities, which determine the state policy in the field of currency regulation, besides, which directly carry out the relevant activity using the instruments specified by the norms of the current legislation;

- it is necessary to improve the relevant legislation, which would correspond to the realities of today and the market conditions, which have developed in Ukraine and in the world.

\section{References:}

Shamova I. V. (2007) Hroshovo-kredytni systemy zarubizhnykh krain dlia spetsialnosti. «Bankivska sprava»: Navch.-metod. posib. Dlia samostiinoho vyvch. Dysts [Monetary systems of foreign countries for specialty. "Banking": Teaching manual for self-studying distantly]. K. KNEU, 160 p. (in Ukrainian)

Shmyreva A. I. (1999) Valyutnoye regulirovaniye i kontrol v sisteme mezhdunarodnykh ekonomicheskikh otnosheniy: monografiya [Foreign exchange regulation and control in the system of international economic relations: monograph]. St. Petersburg, 256 p. (in Russian).

Khamaganova L.D. (2001) Mirovoy opyt v organizatsii valyutnogo regulirovaniya i valyutnogo kontrolya [World experience in the organization of currency regulation and currency control]. Irkytsk, 320 p. (in Russian).

Platonova I.N. (ed). (2006) Valyutnyy kontrol v sisteme finansovogo prava [Currency control in the financial law system], Moscow, 189 p. (in Russian).

Lisovol O.M. (2017) Inozemnyi dosvid finansovo-pravovoho rehuliuvannia valiutnoho kontroliu [Foreign experience of financial and legal regulation of currency control]. Law and society, n. 17, pp. 198-203.

Luchkovska S.I. (2005) Evoliutsiia system valiutnoho kontroliu u rozvynutykh yevropeiskykh derzhavakh: finansovo-pravovi aspekty [Evolution of exchange control systems in developed European countries: financial and legal aspects]. University scientific notes, n. 4, pp. 225-230.

Honcharuk I.V., Matsko O.M., Shparhalo H.Ye. (2010) Dosvid valiutno-kursovoho rehuliuvannia v transformatsiinykh ekonomikakh [Experience of exchange rate regulation in transformational economies]. Visnyk of the Lviv Commercial Academy, n. 33, pp. 176-180.

Sorokivska Z.K. (2013) Zarubizhnyi dosvid realizatsii valiutnoi polityky v konteksti zabezpechennia makroekonomichnoi stabilnosti [Foreign experience in implementing monetary policy in the context of ensuring macroeconomic stability]. Ukrainian Science: Past, Present, Future: Annual, n. 20, pp. 261-272.

Harbinska-Rudenko A.V. (2011) Dosvid valiutnoho rehuliuvannia ta valiutnoho kontroliu za zakonodavstvom Polshchi [Experience in currency regulation and currency control under the legislation of Poland]. I International Scientific Conference, (Ukraine, Kyiv, February 24). Kyiv, National Aviation University, pp. 424-429.

Ivanov D. (1998) Sovremennoye valyutnoye zakonodatelstvo Polshi [Modern currency legislation of Poland]. Financial Business, n. 7, p. 14.

Yurhelevych S. (2000) Valiutne rehuliuvannia : zarubizhnyi dosvid ta propozytsii shchodo Ukrainy (TochkazoruekspertivUkrainsko-yevropeiskohokonsultatyvnohotsentru) [Foreign exchange regulation: foreign experience and proposals on Ukraine (Point of view of experts of the Ukrainian-European advisory center)]. Economics, finance, law, n. 10, p. 4. 